\title{
Extreme territorial aggression by urban Peregrine Falcons toward Common Buzzards in South-West England
}

\author{
Nick DIXON ${ }^{1 *} \&$ Andrew GIBBS ${ }^{2}$
}

Received: October 18, 2018 -Revised: December 12, 2018 -Accepted: December 30, 2018

This is a contribution submitted to the Proceedings of the World Conference on the Peregrine Falcon in Budapest in September 2017.

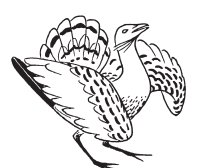

Dixon, N. \& Gibbs, A. 2018. Extreme territorial aggression by urban Peregrine Falcons toward Common Buzzards in South-West England. - Ornis Hungarica 26(2): 232-242. DOI: 10.1515/ orhu-2018-0031 the south-west of England, have been studied in detail since first occupation in 1997. During this period, changes in both male and female falcons have been recorded. Following the arrival of a new female Peregrine in 2009 , a dramatic change in behaviour towards Common Buzzards (Buteo buteo) on passage over the city was noted. Buzzards flying over Exeter are attacked by the falcons, especially so when in proximity to the church. We have attempted to document these attacks through our own observations, with additional information from local residents and wildlife organisations. Further records have come from veterinary surgeries and wildlife rehabilitators regarding injured buzzards found in the city. This paper documents the extreme levels of territorial aggression as demonstrated by the pair of Peregrines during cooperative attacks on Buzzards. We reveal this unique interspecific behaviour by summarising the number, frequency, timing and outcome of attacks undertaken over an eightyear period. We describe and illustrate the strategy employed by the Peregrines during a typical attack, plus consider implications on breeding productivity and the future scenarios should one of the current pair be replaced.

Keywords: Peregrine Falcon, Falco peregrinus, urban nesting, territorial behaviour, Common Buzzard, Buteo buteo, co-operative attack strategy

Összefoglalás A délnyugat-angliai Exeter belvárosában álló templomon fészkelő vándorsólymok (Falco peregrinus) már 1997 óta rendszeresen megfigyelt és vizsgált madarak. Az azóta eltelt időszakban a költőpárt érintő minden egyedi változás, mind hímeket, mind tojókat ideértve, feljegyzésre került. A 2009-ben érkező tojó óta jelentős változás figyelhető meg a város fölött átrepülő egerészölyvekkel (Buteo buteo) szemben tanúsított viselkedésben. Az Exeter fölött megfigyelhetö egerészölyveket - különösképpen akkor, ha a templom irányába haladnak - gyakran megtámadják a vándorsólymok. Elhatároztuk, hogy lejegyezzük ezeket a támadásokat, saját megfigyeléseinket a helybeliek és vadvédelmi szervezetek információival kiegészítve. További adatok álltak rendelkezésre a városban megsérült egerészölyvekröl, amelyeket állatorvosok és vadvédelmi szakemberek szolgáltattak. Jelen tanulmány célja a vándorsólymok egerészölyvekkel szemben mutatott közös támadásainak, agresszív territórium védelmének leírása. Ezt az egyedi, fajok közötti kölcsönhatást az elmúlt nyolc évben megfigyelt támadások számának, gyakoriságának, időzítésének és végkimenetelének közzétételével mutatjuk be. Továbbá részletesen foglalkozunk a vándorsólymok támadási stratégiájának ismertetésével, kitérve a költési siker és a lehetséges jövőbeli változások értékelésére.

Kulcsszavak: vándorsólyom, városi fészkelés, territoriális viselkedés, egerészölyv, együttmüködésen alapuló támadási stratégia

\footnotetext{
${ }^{1}$ Exeter Peregrine Project, Churchgate, Drewsteignton, Exeter EX6 6QU, e-mail: nickdixondevon@aol.com

2 83, Ladysmith Road, Heavitree, Exeter EX12PS, e-mail: a.gibbs123@hotmail.co.uk

* corresponding author
} 


\section{Introduction}

The most recent census to determine the breeding population of the Peregrine in the UK, Isle of Man and the Channel Islands was undertaken in 2014, and estimated at 1,769 pairs, a 22\% increase on the previous survey in 2002 (Wilson et al. 2018). Local populations in some traditional upland regions have declined, but much of the increase is due to increased lowland occupation and breeding in quarries and on a variety of built structures, with the majority being in urban environments.

The first church in the UK to be occupied by Peregrines, following their recovery from the population crash in the 1950's was in Devon, in the south-west of the UK. Peregrines were first recorded at St Michael and All Angels Church in Mount Dinham, Exeter in 1988 with a male holding territory, and with a pair resident in 1989. A nest box was erected in early 1990 but it was not used, and there was only sporadic occupation by a variety of single falcons for the following three years.

An adult pair was observed on the church in April of 1997, and first breeding occurred, with the falcons using a nest constructed earlier in the year on a flat ledge on the north face of the tower by Common Ravens (Corvus corax). This site was used for successful breeding until 2007, when a new female found the original nest box (installed in 1990), and it has been used every year since. Whilst there have been changes of both adult falcons at this site, breeding has occurred every year, fledging 57 young between 1997 and 2017 (mean 2.7 chicks per year). The Peregrines' tolerance of human activity at street level just $30 \mathrm{~m}$ below them allows weekly collections of fallen prey remains with no disturbance to the falcons.

Data from this study, together with detailed observations of behaviour, have provided a valuable opportunity for a long-term study of prey selection and diet, as well as a variety of other aspects of breeding biology and behaviour (Drewitt \& Dixon 2008, Dixon \& Drewitt 2012, Dixon 2017).

During this period, there have been recorded changes in the resident adults, and it is our belief that the current male arrived in March of 2005, and the female took occupancy in March of 2009.

Neither of the resident Peregrines are ringed, and we therefore cannot prove that the same individuals have been paired since 2009, although we strongly believe that this is so. This is due to almost daily observations of familiar behaviour of both birds at the church, by a variety of experienced watchers. There have been no gaps in occupation by either bird, and since they hold territory all year they can both be seen daily on regular perches.

\section{Territorial interactions with Common Buzzards}

In May of 2012, we heard that the Peregrines had attacked and knocked down a Common Buzzard near the church, and then attacked another one a few days later. This was new behaviour for the Exeter Peregrines, as Buzzards were often to be seen passing high over the city, but there had never been any interaction between the species.

The first confirmed record of this territorial aggression occurred a month later, on the $9^{\text {th }}$ of June, 2012, during the weekend that the juveniles fledged, when A. Gibbs saw both adult 
Peregrines attacking a Buzzard. The Peregrines repeatedly stooped onto the Buzzard high over the city, hitting it and causing it to fall. A. Gibbs was able to pinpoint its location and found it dead, $480 \mathrm{~m}$ to the east of the church. Later that day, we learnt that another attack had been witnessed during the morning, and the dead Buzzard also retrieved. Both Buzzards were easily found due to the loud and persistent alarm calling by corvids and gulls, which were surrounding and noisily mobbing the dead bird on the ground. Further attacks by the Peregrines were witnessed over the next few weeks, and A. Gibbs found another dead Buzzard which had fallen into the nearby river Exe, $150 \mathrm{~m}$ from the church. Ten attacks were observed or reported with four Buzzards seen knocked down over the city during 2012.

Many of these observed attacks on Buzzards involved both falcons working together in what appeared to be co-operative behaviour.

These events were later published in 'Devon Birds' to raise awareness of this behaviour, as such extreme levels of aggression by one pair of Peregrines appear not have been recorded before in the UK (Dixon 2013).

Following the attacks on Buzzards witnessed in 2012, we reviewed the recorded observations from previous yearly visits to the church during N. Dixon's weekly collections to retrieve prey items as part of a study into the diet and prey selection of the Exeter Peregrines. This confirmed that the first record of territorial aggression occurred in 2009, shortly after the arrival of the current female, when she repeatedly stooped onto a Buzzard near the church and drove it away. N. Dixon also recorded the first sighting of both Peregrines chasing a Buzzard the following year in 2010, but the outcome was unseen due to losing sight of the birds behind tall buildings. We also learnt of three attacks involving both falcons in 2011, seen by a photographer during the fledging period in early June.

It became apparent that the attacks on Buzzards began with the arrival of the new female in 2009 and although it had taken some time to understand what was happening, we were keen to see whether this level of aggression was maintained by the current pair of Peregrines in subsequent years.

\section{Methods}

During the following breeding seasons 2013 to 2017, where time allowed, we increased the frequency of our visits to the church to observe the territorial behaviour of the pair. A. Gibbs was often able to visit on most days during May and June, the months when previous attacks were most prevalent. These specific watches were undertaken from the top deck of a public car park, $250 \mathrm{~m}$ from the church, with panoramic views of the sky above Exeter. N. Dixon continued with weekly visits to the church to collect fallen prey remains, plus undertook occasional extended watches during May and June.

Both morning and afternoon watches were undertaken whenever possible, between two and four hours in duration during favourable weather conditions. Binoculars proved to be more useful than a telescope, offering a wide field of view and enabling the watcher to keep up with fast-moving events more easily, with many attacks easily observed by the naked eye. 
The following details of each attack were recorded, whenever possible: a) initial location of Buzzard when first attacked, b) escape/attempted escape direction of Buzzard, c) final outcome of attack, d) location of any Buzzard brought down by the attack, e) nature of attack (by one or both members of the pair), f) number of stoops made during attack, g) time and duration of attack.

In addition to our actual observations, and reported sightings from members of the public, we informed local wildlife groups and bird watching organisations to increase awareness and asked them to record any interactions seen. Local veterinary surgeries, wildlife hospitals and rehabilitators were also contacted to make them aware of this behaviour and report any Buzzards found dead or injured in Exeter.

\section{Attack strategy}

The first indication that a Buzzard is present will be alarm-calling by one of the falcons, whether they are on their regular perches on the church or soaring high over the city. At this stage, the passing Buzzard may be almost invisible to the human eye due to its height over the city or its distance from the church.

The falcons will undertake a determined flight towards the Buzzard, whilst still alarm calling, either from the church, or from a high soaring position elsewhere in the sky. If one or both falcons begin their flight from the church, then considerable time and effort are required to get to a position above the Buzzard before an attack starts. Once they have gained sufficient height above the Buzzard, the attack will involve repeated individual vertical stoops down onto it, with immediately looping back up again to repeat the action. During a co-operative attack, the male Peregrine will stoop first, passing close enough to cause the Buzzard to 'flip' upside down to present its talons in defence. The female Peregrine will follow almost immediately aiming to hit the Buzzard on its head, wing or back as soon as it has righted itself, and before it has time to present its talons again.

The falcons will both continually loop back up again to a position above the Buzzard to begin repeated attacks. These synchronised 'stoop cycles' continue until the Buzzard reaches a territory boundary and the attacks are given up, or until the Buzzard is hit and knocked down.

All attack stoops made by the Peregrines are vertical or near-vertical, from an elevated position directly above the Buzzard. Sometimes an attack begins as a 'solo attack', usually when the adults are patrolling in different parts of the territory, or one is on the church. Alarm calls by the solo attacker alert the second adult and the described pattern of stoop cycles is usually initiated quickly.

When synchronicity is lost during 'stoop cycles', it is not uncommon to see either Peregrine 'waiting on' briefly above the Buzzard for its partner, to 'reset' the timing of attack.

The Buzzard's attempts to fly away are slowed by the repeated talon-presenting 'flips' in defence of an attack, but many Buzzards will escape if their flight direction takes them further away from the church. Once they reach a territorial boundary some distance from the church, the Peregrines will give up on the chase. It is unfortunate that a Buzzard under attack from repeated stoops is unaware that if its intended direction of escape takes it closer to the church, the more likely it will be subjected to increased attacks with greater ferocity. 
If a Buzzard has been hit and fallen to the ground, gulls and corvids immediately take to the air and mob the Buzzard, especially if it has fallen onto a roof top or the ground but away from passers-by. After a successful attack, the Peregrines will either fly back to the church or return to soaring over the city. Occasionally, they appear unsettled and will give 'low intensity' alarm calls for up to two hours, while keeping watch, especially if a Buzzard has been injured and fallen but taken refuge in trees. In this case, behaviour during this period includes brief periods of alarm calling while making short return flights out from regular perches or from the entrance to the nest box. If the weather conditions are calm, one of the adult falcons, invariably the male, will often perch on the metal cross on the very top of the spire (72 $\mathrm{m}$ above ground level).

\section{Annual frequency of attacks on Common Buzzards}

Attacks on Buzzards by the Peregrines fall into two main categories: those by the pair and those by a single bird. Table 1 shows all observed attacks on Buzzards from 2009 to 2017, with a total of 455 observed attacks, with 52 downed Buzzards. When adding the 18 injured or dead Buzzards found within $700 \mathrm{~m}$ of the church in Exeter over this period where no attack was observed, the totals increase to 70 downed Buzzards from 473 attacks.

What is of interest, is that of the 455 observed attacks, 275 (60.4\%) involved both falcons working together in highly effective co-operative behaviour, that often results in the Buzzard being hit and knocked down. The female alone has undertaken 118 observed attacks (25.93\%) compared to the male at just $41(9.01 \%)$.

The territorial attacks on Buzzards in 2012 were all recorded on days of good weather, often with blue skies, sun and some wind, and so from 2013, we tried to increase our observations of

Figure 1. Map of Exeter city centre showing the locations of the 70 downed Common Buzzards described in the text. The map is a $2 \mathrm{~km} \times 2 \mathrm{~km}$ square centred on St. Michaels and All Angels church, and the inner circle shows a radius of $500 \mathrm{~m}$ from the church. This map contains public sector information licensed under the Open Government Licence v3.0. This map has been updated, having first being featured in British Birds. Image by Fluke Art

1. ábra Exeter belvárosának térképe feltüntetve a szövegben részletezett 70 egerészölyv pusztulás helyét. A térkép egy $4 \mathrm{~km}^{2}$ nagyságú területet mutat a St. Michaels and All Angels templomot középre igazítva, egy

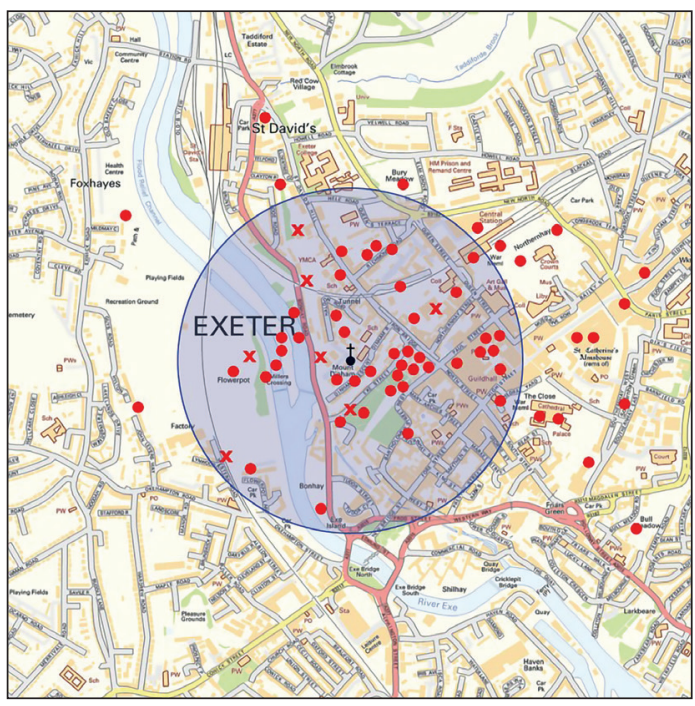
500 m sugarú körlappal lefedve a templom környékét. A térkép az Open Government Licence v3.0 által meghatározott nyilvános adatokat tartalmaz. A térkép a British Birds lapban történő megjelenése óta frissítve. Készítette: Fluke Art 
Table 1. Yearly totals of observed attacks by Peregrine Falcons on Common Buzzards in Exeter (2009-2017) NB. Outcome of Observed attacks. Buzzards seen hit and knocked down are recorded as 'Downed'. If the Buzzard was seen to fly off following an attack, it was 'Driven off', and 'Unseen' refers to attacks where the outcome was obscured by buildings or trees in the foreground.

1. táblázat $\mathrm{A}$ vándorsólyom egerészölyvek ellen indított támadásainak összesített értékei éves bontásban Exeter városában (2009-2017)

\begin{tabular}{|c|c|c|c|c|c|c|c|}
\hline Year & $\begin{array}{c}\text { No. of } \\
\text { Attacks }\end{array}$ & By Pair & $\begin{array}{c}\text { By } \\
\text { Female }\end{array}$ & By Male & $\begin{array}{c}\text { Reported } \\
\text { attack, details } \\
\text { unknown }\end{array}$ & $\begin{array}{c}\text { Downed } \\
\text { Buzzards }\end{array}$ & $\begin{array}{c}\text { Outcome } \\
\text { unseen/ } \\
\text { Driven off }\end{array}$ \\
\hline 2009 & 1 & & 1 & & & & 1 \\
\hline 2010 & 1 & 1 & & & & & 1 \\
\hline 2011 & 3 & 3 & & & & & 3 \\
\hline 2012 & 10 & 7 & & 3 & & $4(1)$ & 6 \\
\hline 2013 & 45 & 38 & 1 & 4 & 2 & $10(7)$ & 33 \\
\hline 2014 & 43 & 32 & 7 & 3 & 1 & $3(1)$ & 40 \\
\hline 2015 & 217 & 121 & 59 & 26 & 11 & 26 & 191 \\
\hline 2016 & 92 & 40 & 44 & 4 & 4 & $6(6)$ & 86 \\
\hline 2017 & 43 & 33 & 6 & 1 & 3 & $3(3)$ & 40 \\
\hline Totals & $\mathbf{4 5 5}$ & $\mathbf{2 7 5}$ & $\mathbf{1 1 8}$ & $\mathbf{4 1}$ & $\mathbf{2 1}$ & $\mathbf{5 2 ( 1 8 )}$ & $\mathbf{4 0 1}$ \\
\hline
\end{tabular}

the falcons during May and June. It is at the point when the young no longer require brooding, around 12-14 days after hatching, that the behaviour of the adult Peregrines appears to change, and they become far more aggressive towards Buzzards. At this stage, both adults spend much more time perching out of sight of the young but return to feed them regularly. In the three weeks prior to fledging, when absent from regular perches on the church, the adults were often to be found soaring high over the city. Initially, we assumed that this was hunting behaviour, but after many hours of observation we now believe that the main purpose of this behaviour is to patrol the territory. Our increased interest and monitoring of this behaviour resulted in 45 observed attacks and 17 Buzzards downed throughout the year.

2014 was an interesting year with 43 attacks observed, but with only 4 downed Buzzards. During our intentional watches, we attempted to record the number of stoop-cycles during each co-operative attack. We recorded between one and 12 stoop-cycles (i.e. 2 to 24 individual stoops) per attack, with a mean of five cycles. It was apparent that, depending on the initial location of the Buzzard, a single cycle is often sufficient to drive away a Buzzard if the attack starts close to the territory boundary.

Our increased watches plus additional records from local observers in 2015 resulted in figures that were totally unexpected in comparison to previous years. We recorded 217 attacks with 26 Buzzards knocked down, but this huge increase was due to a variety of factors. There were far higher numbers of Buzzards seen over Exeter than in previous years and A. Gibbs was able to spend many hours on watch during the spring and early summer months, and also enlisted the help of Exeter University Zoology undergraduates as additional observers. 
Table 2 shows the monthly counts of attacks observed over Exeter through 2015, with attacks recorded in January and February. Egg laying began on $22^{\text {nd }}$ March, with a clutch of four eggs laid by the $30^{\text {th }}$ March. Incubation occurred throughout the month of April, but only two eggs hatched on the $30^{\text {th }}$ April and the $2^{\text {nd }}$ of May. Prior to hatching, most attacks on Buzzards were by the male as the female undertook most of the incubating.

The juvenile Peregrines no longer needed constant brooding from the $12^{\text {th }}$ May, but we had already recorded dual attacks during this month, when the adult Peregrine, invariably the female would leave the juveniles and join its partner to attack Buzzards. It was during May and June (when the pair are at their most aggressive) that 145 attacks were carried out by the pair working cooperatively, resulting in 21 Buzzards being knocked down.

Two separate Buzzards were attacked and knocked down in May 2015 by the female Peregrine acting on her own, something we had never recorded before. During the first of these attacks, she descended in a high velocity stoop from a very high altitude down over the city at an angle of approximately 35 degrees in what we perceived as a 'hunting style' stoop, taking approximately seven seconds to reach the Buzzard which was soaring at a much lower altitude. This caught the Buzzard completely by surprise and it had no time to defend itself. The female struck the Buzzard then looped up to stoop down again, but the Buzzard was already falling with what appeared to be one wing trailing. This style of attack by the female has now been observed on four further occasions (Dixon \& Gibbs 2015a, 2015b).

The second event occurred when she flew straight out from the church and North-eastwards toward the University, and then having gained height, she undertook a single stoop before striking a Buzzard which was gaining altitude having flown out from trees in the University grounds.

Table 2. Attacks by Peregrine Falcons on Common Buzzards in Exeter during 2015

2. táblázat Vándorsólyom támadások egerészölyvek ellen Exeterben 2015-ben

\begin{tabular}{|c|c|c|c|c|c|c|}
\hline Month & $\begin{array}{c}\text { No. of } \\
\text { attacks }\end{array}$ & By the pair & By Female & By Male & $\begin{array}{c}\text { Reported } \\
\text { attack, } \\
\text { full details } \\
\text { unknown }\end{array}$ & $\begin{array}{c}\text { No. of } \\
\text { Buzzards } \\
\text { downed }\end{array}$ \\
\hline January & 2 & 1 & - & 1 & - & - \\
\hline February & 3 & 3 & - & - & - & - \\
\hline March & 14 & 8 & - & 5 & 1 & - \\
\hline April & 26 & 3 & 6 & 14 & 3 & - \\
\hline May & 60 & 41 & 13 & 3 & 3 & 12 \\
\hline June & 85 & 50 & 32 & 1 & 2 & 9 \\
\hline July & 9 & 4 & 4 & 1 & - & 1 \\
\hline August & 4 & 3 & - & - & 1 & 1 \\
\hline September & 11 & 7 & 3 & 1 & - & 3 \\
\hline October & 3 & 1 & 1 & - & 1 & - \\
\hline November & - & - & - & - & - & - \\
\hline December & - & - & - & - & - & - \\
\hline Total & $\mathbf{2 1 7}$ & $\mathbf{1 2 1}$ & $\mathbf{5 9}$ & $\mathbf{2 6}$ & $\mathbf{1 1}$ & $\mathbf{2 6}$ \\
\hline
\end{tabular}


In 2016, 92 attacks were observed, again with the additional help of watches by the Exeter University students, with six Buzzards seen knocked down and a further six found dead or injured in the city (Dixon \& Gibbs 2016).

Unfortunately, work and other commitments reduced the time that we and other observers could spend on intentional watches in 2017, and only 43 attacks were observed, with three Buzzards seen knocked down and a further three recovered in the city.

Having spent considerable time observing this behaviour, it is apparent that Buzzards can be seen passing over the city at a range of altitudes from about $60 \mathrm{~m}$ above ground level to such a height that they are barely visible to the human eye and can be moving in any direction across the city. It is apparent that an extraordinary amount of effort is put into attacking any Buzzard encroaching into the Peregrines territory, by both adult falcons, and especially by the female. It is not unusual to observe the pair 'ringing up' to gain height for several minutes, in order to reach a Buzzard flying across the city at high altitude, and then launch an attack with multiple stoops. The longest flight we have observed to attain height above a passing Buzzard, prior to then mounting an attack, was on the $16^{\text {th }}$ of June, 2015. The female took just under 10 minutes from the first alarm calling and leaving the church, to get to a position above a very high soaring Buzzard. This involved alternate direct fast wing flapping flights into the head wind combined with circular 'ringing up' flights before gaining height above the Buzzard and then making a number of direct solo stoops, which then drove it to the north. The previous week, on another intentional watch day on the $7^{\text {th }}$ June, along with several members of the Gloucester Raptor Monitoring Group, 13 Buzzards overflying the city were attacked, with one downed and a total of 200 stoops counted.

The longest attack over the city to date has been timed at nine minutes, when a Buzzard was repeatedly stooped on over the city and driven east, almost to the territory boundary in 2014. In attempting to escape, the Buzzard then turned and flew back towards the city centre, under constant attack, before we lost sight of the birds as they headed north. A more typical attack, captured by a BBC film crew on $26^{\text {th }}$ June 2013, showed the adults making 21 stoops in total on a Buzzard during an attack period of 1 minute 52 seconds.

\section{Seasonal and diurnal timing of attacks from DB}

Attacks observed between 2009 and 2017 have been recorded in all months of the year except December, with most from April through to August but with a dramatic increase in May and June, during the pre- and post-fledge period. This is due to a combination of factors: the juvenile Peregrines in the nest no longer need brooding, so both adult Peregrines are often to be found soaring over the city during periods of good weather, and the warmer conditions increase the likelihood of Buzzards moving across the region.

Attacks on Buzzards over the city mainly occur between 10.00 and 16.00 BST, which corresponds with the period of most Buzzard soaring activity during spring and summer (Dare 2015).

All the Buzzards that we have recovered after an attack by the falcons, either alive, injured or dead have been sub-adults, showing streaked plumage on the breast and a variety of wing and tail moult stages, indicating they are all between one and three years old. Eleven Common Buzzards have now been sent to the Predatory Bird Monitoring Scheme (P.B.M.S) at the 
Centre for Ecology and Hydrology (C.E.H) Lancaster for tissue and organ sampling, and analysis. Full details have not yet been received on all the carcasses sent but initial findings show both male and female Buzzards in the sample. This would confirm our observations that any Buzzard over the city in the Peregrines territory is likely to be attacked, suggesting there is no bias towards the smaller males, and that the larger females are just as likely to be knocked down. Ongoing information from vets and the Royal Society for the Prevention of Cruelty to Animals (RSPCA) indicate that Buzzards recovered alive following an attack by the falcons are often underweight, confirming what we have found when weighing dead Buzzards.

\section{Territorial interaction with other species}

The Exeter Peregrines only exhibit this extreme territorial aggression towards Common Buzzards and show little interest in the many other species that pass through their territory or high over the city. No attention is paid to (Great) Cormorant (Phalacrocorax carbo) or Little Egret (Egretta garzetta) that regularly fly up the river Exe, passing in very close proximity to the spire of the church. There are very occasional and brief skirmishes with Common Ravens (Corvus corax), Carrion Crows (Corvus corone) and the larger gull species involving little more than a single short stoop or fly-by, but with none of the intensity or aggression as that shown to any Buzzard within a kilometre of the church. Passing Red Kites (Milvus milvus) have been subject to varying degrees of behaviour, ranging from brief attention to occasional attacks by single falcons or the pair, but again these attacks have lacked intensity and have not involved synchronised the recognised 'stoop cycles'. Eurasian Sparrowhawk (Accipiter nisus) has been occasionally recorded as prey (Dixon \& Drewitt 2012), and are often seen flying around the spire and above the nearby rooftops while the Peregrines are perching on the stone pinnacles at the same height, and they instigate no interest whatsoever.

\section{Discussion}

Peregrines and Buzzards are often found in the same traditional habitats, such as sea cliffs and upland crags, and increasingly across lowland regions as both species increase their ranges. Aerial encounters, mobbing and skirmishes can be frequent, or the two species may totally ignore the other. There are historical records of Peregrines killing Buzzards in the UK, and their remains have been recovered at Peregrine eyries, although this is very rare (Tubbs 1974, Ratcliffe 1993).

There can be no doubt that the extreme territorial aggression exhibited by the Exeter Peregrines towards Buzzards is unique, as this behaviour is not currently recorded anywhere else in the UK.

Since the arrival of the current female in 2009, they have knocked down 70 Buzzards from over 470 attacks over the city, up to the end of 2017 . We strongly believe these figures to be the tip of the iceberg, and that many attacks are neither seen nor reported to us.

We started undertaking intentional watches from the car park roof in 2013, and whether it is a short watch of two hours or a day watch of six to eight hours, invariably the attacks that 
we observe are not subsequently reported to us by other local observers. This would indicate that in our absence, and on days of favourable weather when Buzzards are likely to be passing over Exeter, many interactions will be missed.

It is on these intentional watches, and when we are joined by other interested raptor workers, that the conversation often turns to why do this pair, or specifically the female, show such extreme levels of aggression towards Buzzards and why they, or specifically the female who appears to have instigated this, invest so much time and energy into this behaviour.

These are interesting questions especially given that attacking a Buzzard carries a high risk of incurring an injury to the Peregrine, and that Buzzards moving at high altitude over the city pose no threat to the falcons or their young. We will never know the cause of this behaviour and can only speculate that something must have happened in the past to trigger the current levels of aggression.

We have considered what the effects of this behaviour may have on breeding productivity as the female has demonstrated that she will leave eggs and newly hatched young in the nest to chase and attack buzzards.

The juvenile Peregrines have been observed joining in with attacks every year since 2013, often from late July and into September. These incidents are occasional rather than regular but raises the question as to whether they will take this learned behaviour into new territories and continue as adults. We began ringing and colour banding in 2012 and are currently only aware of one of the juveniles that fledged from the church (a male in 2015) which has established its own territory. This is on a church in a town approximately 30 miles away, which it first occupied in 2017, and bred successfully in 2018. There have been no territorial incidents with Buzzards there to date.

On a final note, we are watching with interest as to when we get a change of partner at the church, and what will happen next. If we are correct as to the dates of both falcons first occupation, it is likely the current male that will be replaced first, with a younger and fitter Peregrine.

If this should occur, will a new male learn and indulge in the current and highly effective co-operative behaviour towards Buzzards or leave it to the female? And if the female were to disappear or be replaced, it would be fascinating to see whether the male Peregrine would continue with attacks on Buzzards over Exeter.

\section{Acknowledgments}

We are indebted to all those who have submitted records of attacks and information during this study, especially from members of the Exeter Peregrine Project, the RSPB and Devon Wildlife Trust in Exeter. We are also indebted to John Gale at City Vets, St. David's veterinary practice and the RSPCA in Exeter and at West hatch, Taunton for information of Buzzards found injured in the city. We would like to give special thanks to Richard Sale, for use of his image and calculations of an observed attack, and to Julie Dando of Fluke Art for the updated map of downed Buzzards, first featured in British Birds, with kind permission from Roger Riddington. 


\section{References}

Dare, P. 2015. The Life of Buzzards. - Whittles Publishing Ltd., Scotland

Dixon, N. 2013. Peregrine aggression towards Buzzards at St. Michael's church, Exeter. - Devon Birds 66(1): $30-31$.

Dixon, N. 2017. The Exeter Peregrines. A brief history of the Peregrine Falcons at St. Michaels and All Angels church, Mount Dinham. - Exeter

Dixon, N. \& Drewitt, E. J. A. 2012. A fifteen-year study of the diet of urban nesting Peregrines. - Devon Birds 65(1): 19-30.

Dixon, N. \& Gibbs, A. 2015a Cooperative attacks by urban Peregrines on Common Buzzards. - British Birds 108: 253-263.

Dixon, N. \& Gibbs, A. 2015b Territorial aggression shown by urban Peregrines towards Common Buzzards. Devon Birds 68(2): 13-20.

Dixon, N. \& Gibbs, A. 2016. Cooperative attacks by urban Peregrines on Common Buzzards: an update. - British Birds 109: 411-416.

Drewitt, E. J. A. \& Dixon, N. 2008. Diet and prey selection of urban-dwelling Peregrine Falcons in southwest England. - British Birds 101: 58-67.

Ratcliffe, D. A. 1993. The Peregrine Falcon. $2^{\text {nd }}$ ed. - T \& AD Poyser, London

Tubbs, C. R. 1974. The Buzzard. - David \& Charles, Newton Abbot

Wilson, M. W., Balmer, D. E., Jones, K., King, V. A., Raw, D., Rollie, C. J., Roony, E., Ruddock, M., Smith, G. D., Stevenson, A., Stirling-Aird, P. K., Wernham, C. V., Weston, J. M. \& Noble, D. G. 2018. The breeding population of the Peregrine Falcon Falco peregrinus in the United Kingdom, Isle of man and Channel Islands in 2014. - Bird Study 65(1): 1-19. DOI: 10.1080/00063657.2017.1421610

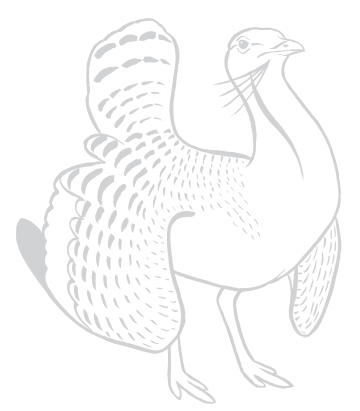

